\title{
STRATEGI IMPLEMENTASI KEBIJAKAN HUTAN TANAMAN RAKYAT DI KPH GEDONG WANI
}

\author{
Irwan Sukri Banuwa, Rahmat Safe'i, Indra Gumay Febryano dan Dian Novayanti \\ Jurusan Kehutanan dan Magister Kehutanan Universitas Lampung \\ Email: diannova_nova@ymail.com
}

\begin{abstract}
ABSTRAK. Hutan Tanaman Rakyat (HTR) merupakan program dari Kementerian Lingkungan Hidup dan Kehutanan untuk mengurangi laju kerusakan hutan dan mengentaskan kemiskinan masyarakat. Program ini membutuhkan partisipasi dari masyarakat untuk mengelola hutan produksi dan mengembalikan fungsinya. Tujuan penelitian ini adalah :1) mengetahui tingkat partisipasi masyarakat terhadap hutan tanaman rakyat, 2) Mengetahui faktor-faktor yang mempengaruhi tingkat partisipasi masyarakat, dan 3) Membangun strategi impelemtasi kebijakan HTR. Data dianalisis dengan analisis desktriptif, regresi berganda, SWOT, dan QSPM. Data dalam penelitian ini berasal dari hasil wawancara terhadap 95 responden yang berasal dari 5 desa penerima IUPHHK HTR di KPH Gedong Wani. Hasil penelitian menunjukan bahwa tingkat partisipasi masyarakat terhadap HTR di KPH Gedong Wani termasuk kategori sedang. Faktor-faktor yang berpengaruh nyata terhadap tingkat partisipasi adalah manfaat, sosialisasi, tenaga pendamping, dan dukungan. Hasil penelitian menunjukan bahwa diperlukan strategi implementasi kebijakan hutan tanaman rakyat, yaitu dengan meningkatkan kualitas dan kuantitas penyuluh.
\end{abstract}

Kata kunci: strategi, Hutan Tanaman Rakyat (HTR), Kerusakan Hutan

\section{POLICY IMPLEMENTATION STRATEGY OF COMMUNITY PLANTATION FOREST IN KPH GEDONG WANI}

\begin{abstract}
Community Plantation Forest (HTR) is a program of the Ministry of Environment and Forestry to reduce the rate of forest destruction and alleviate the poverty of the community. This program requires the participation of communities to manage production forests and restore their functions. The objectives of this research are: 1) to know the level of people's participation in community forest plantations, 2) to know the factors that influence the level of community participation, and 3) to develop the strategy of impelemtation of HTR policy. Data were analyzed by descriptive analysis, multiple regression, SWOT, and QSPM. The data in this study comes from interviews of 95 respondents from 5 villages receiving IUPHHK HTR in KPH Gedong Wani. The results showed that the level of community participation on HTR in KPH Gedong Wani included in medium category. Factors that significantly affect the level of participation are benefits, socialization, co-workers, and support. The result of the research shows that it is necessary to implement the policy strategy of community forest plantation by improving the quality and quantity of extension agent.
\end{abstract}

Key word: strategy, Community Plantation Forest (HTR, Forest Destruction

\section{PENDAHULUAN}

Kesatuan Pengelolaan Hutan (KPH) Gedong Wani merupakan salah satu otoritas pengelolaan hutan di Provinsi Lampung yang seluruh kawasannya telah diokupasi oleh masyarakat perambah. Di dalam kawasan seluas 30.324 hektar kini tidak dapat lagi dijumpai areal yang berhutan melainkan berupa $70,6 \%$ pertanian lahan kering; $13,71 \%$ kebun campuran; $8,62 \%$ pemukiman; $6,72 \%$ lahan terbuka dan $0,28 \%$ berupa industri skala besar pengolahan hasil pertanian seperti kepala sawit, tapioka dan lain-lainnya. Bahkan di kawasan hutan produksi ini tercatat ada 39 desa definitif dalam11 kecamatan definitif lengkap dengan fasilitas umum termasuk jaringan jalan beraspal hotmix, kantor desa, kantor camat, sekolah dasar sampai perguruan tinggi, puskesmas, pasar, tempat ibadah, polsek, koramil dan sebagainya (Dishut Provinsi Lampung, 2013). Permasalahan ini berakar dari pertumbuhan penduduk yang semakin meningkat. Pertambahan penduduk menuntut tercukupinya kebutuhan pangan, kebutuhan kayu bakar, kebutuhan kayu pertukangan, dan tempat pemukiman. (Senoaji, 2011).
Dinas Kehutanan Provinsi Lampung (Dishut Prov) Lampung sudah lama tidak mampu mengusir perambah yang sudah tinggal selama bertahun-tahun di kawasan KPH Gedong Wani tersebut. Untuk mengusir perambah merupakan pekerjaan berat dan sangat mahal yang dapat dikatakan hampir tidak mungkin apalagi jika dipersyarakatkan tanpa ada gejolak sosial. Namun di sisi lain otoritas Dishut Provinsi Lampung mempunyai tugas untuk melestarikan hutan.

Kartodiharjo (2007) berpendapat bahwa kerusakan hutan tidak mungkin dapat dihentikan tanpa dibangunnya kondisi yang memungkinkan tumbuhnya kepedulian masyarakat terhadap hutan. Dengan kata lain keterlibatan masyarakat sekitar hutan dalam pengelolaan hutan merupakan suatu keharusan. Simon (2000) menjelaskan bahwa pada waktu lampau, pengelolaan hutan menekankan pada pendekatan teknik dan ekonomi. Namun sekarang rimbawan dituntut untuk menfokuskan masalah sosial sebagai bagian dari proses pengelolaan hutan yang lestari. Memecahkan masalah sosial memerlukan sebuah pemahaman terhadap nilainilai yang dipegang oleh masyarakat dan partisipasi 
dari kelompok masyarakat kunci dalam membuat keputusan tentang pengelolaan hutan. Sekarang ini kunci keberhasilan pengelolaan sumberdaya hutan ditentukan oleh keberhasilannya dalam memecahkan masalah sosial ekonomi masyarakat. Gagal dalam pemecahan masalah ekonomi masyarakat, akan gagal pula dalam upaya pengelolaan hutan (Simon, 2001).

Untuk mengurangi laju kerusakan hutan sekaligus meningkatkan keterlibatan masyarakat sekitar hutan dalam pengelolaan hutan, maka pemerintah melalui Kementerian Lingkungan Hidup dan Kehutanan mencanangkan program Perhutanan Sosial. Tujuan pengembangan perhutanan sosial adalah meningkatkan peran serta masyarakat dalam mengelola hutan sehingga dapat meningkatkan taraf kehidupan masyarakat sekitar (Sumanto, 2009). Dasar hukum pelaksanaan program Perhutanan Sosial adalah Peraturan Menteri Lingkungan Hidup dan Kehutanan Nomor P.83/MENLHK/SETJEN/ KUM.1/10/2016 tentang Perhutanan Sosial. Di dalam peraturan tersebut terdapat skema-skema pengelolaan hutan berbasis masyarakat seperti Hutan Desa, Hutan kemasyarakatan, hutan tanaman rakyat, hutan rakyat, hutan adat, dan kemitraan kehutanan.

Kebijakan pembangunan HTR terkait dengan kebijakan pemerintah untuk mengentaskan kemiskinan, menciptakan lapangan kerja baru, dan memperbaiki kualitaspertumbuhanmelalui investasiyang proporsional antar pelaku ekonomi.( Noordwjik et al. 2007). Selain itu kebijakan ini dimaksudkan untuk memberikan akses hukum, akses lembaga keuangan dan akses pasar yang lebih luas kepada masyarakat dalam pemanfaatan hutan produksi dalam kerangka mensejahterakan masyarakat dan mewujudkan pengelolaan hutan lestari (Emila dan Suwito 2007). Kepastian jaminan akses tersebut merupakan syarat untuk keberhasilan program-program pengelolaan hutan yang melibatkan masyarakat (Nawir et al 2007).

Saat ini, Kementerian Lingkungan Hidup dan Kehutanan telah memberikan Izin Pemanfaatan Hasil Hutan Kayu pada Hutan Tanaman Rakyat (IUPHHKHTR) kepada 5 Desa yaitu Desa Budi Lestari, Desa Sinar Ogan, Desa Jati Baru, Desa Srikaton, dan Desa Jati Indah yang terletak di Register 40 KPH Gedong Wani Kecamatan Tanjung Bintang, Kabupaten Lampung Selatan, Provinsi Lampung. Permohonan untuk IUPHHK-HTR ini telah dilakukan oleh masyarakat sejak tahun 2014 dan baru diberikan ijin oleh Kementerian pada Bulan Maret tahun 2017. Sekalipun demikian, dalam implementasinya skema HTR menjadi persoalan lain yang tidak sederhana dalam kawasan hutan tersebut. Umumnya para petani tidak puas bila hanya diakui sebagai pemegang hak guna atas semua lahan yang telah mereka kuasai sekarang. Mereka umumnya menginginkan agar menjadi hak milik melalui suatu proses pelepasan kawasan hutan. Hal ini menyebabkan masyarakat tidak mau terlibat atau berpartisipasi dalam kegiatan HTR. Hal ini akan mempengaruhi kesuksesan program HTR. Padahal keterlibatan masyarakat turut mempengaruhi kesuksesan sebuah program. Kumba (2003) mengatakan kesuksesan sebuah program dapat terlaksana melalui peran partisipasi masyarakat secara langsung yang bermukim di mana program tersebut akan dilaksanakan. Jika masyarakat masih ragu untuk berpatisipasi dalam mensukseskan program HTR, maka akan menyebabkan lambannya pembangunan HTR.

Stringer (2013) memberikan pendapatnya bahwa berpartisipasi adalah keikutsertaan suatu kelompok masyarakat dalam program-program pemerintah. Menurut Papilla (2012), Masyarakat akan tergerak untuk berpartisipasi dalam suatu kegiatan apabila 1) dilakukan melalui organisasi yang sudah dikenal atau yang sudah ada di tengah masyarakat yang bersangkutan, 2) partisipasi memberikan manfaat langsung kepada masyarakat yang bersangkutan, (3) manfaat yang diperoleh tersebut dapat memenuhi kepentingan masyarakat setempat, dan (4) dalam proses partisipasi terdapat jaminan kontrol oleh masyarakat.

Implementasi program HTR ini kerap kurang berhasil dikarenakan: partisipasi rendah, program tidak tepat sasaran karena informasi tidak akurat, teknologi tidak sesuai kebutuhan, informasi dan inovasi. Oleh karena itu dibutuhkan strategi yang tepat untuk mengimplementasikan kebijakan hutan tanaman rakyat agar tidak berujung kepada kegagalan. Sebagai langkah awal menuju suatu proses kerjasama antar pelaku, perlu dilakukan studi tentang tingkat partisipasi petani penggarap terhadap program yang telah dilakukan sampai saat ini (Desmiwati, 2016). Berdasarkan beberapa uraian tersebut di atas maka dilakukanlah penelitian dengan fokus untuk mengkaji partisipasi masyarakat terhadap pembangunan HTR di Wilayah KPH XIV Gedong Wani yang nantinya dapat digunakan untuk merencanakan langkah-langkah kebijakan yang diperlukan untuk meningkatkan partisipasi masyarakat.

\section{METODE}

Penelitian ini dilaksanakan dari bulan Maret sampai Juli 2017 di Desa Budi Lestari, Desa Sinar Ogan, Desa Jati Baru, Desa Srikaton, dan Desa Jati Indah yang merupakan areal HTR di Register $40 \mathrm{KPH}$ XIV Gedong Wani, Kecamatan Tanjung Bintang, Kabupaten Lampung Selatan, Provinsi Lampung. Pemilihan lokasi penelitian dilakukan secara sengaja (purposive) dengan pertimbangan bahwa lokasi tersebut telah memiliki ijin pemanfaatan hasil hutan kayu hutan tanaman rakyat (IUPHHK-HTR) sejak tahun 2017 sehingga program HTR dapat dilaksanakan.

Metode penelitian yang digunakan adalah dengan menggunakan kuisioner. Teknik pengumpulan data meliputi pengamatan, wawancara, dan dokumentasi. Untuk mengetahui faktor-faktor yang berpengaruh nyata 
terhadap tingkat partisipasi maka digunakan analisis regresi berganda. Strategi implementasi kebijakan HTR menggunakan analisis SWOT. Responden terpilih sejumlah 95 orang dipilih secara acak dari 1866 populasi dengan menggunakan rumus slovin. Pengolahan dan analisis data meliputi 1) analisis deskriptif mengenai tingkat partisipasi masyarakat terhadap implementasi HTR, 2) Analisis regresi berganda untuk mengetahui faktor-faktor yang berpengaruh terhadap tingkat partisipasi masyarakat, 3)Analisis strategi implementasi kebijakan HTR melalui tiga tahap, yaitu : pengumpulan data, analisis SWOT, dan pengambilan keputusan dengan menggunakan analisis QSPM (Rangkuti, 2008)

\section{HASIL DAN PEMBAHASAN}

\section{A. Tingkat partisipasi masyarakat dalam implementasi HTR}

Partisipasi masyarakat pada kegiatan pembangunan hutan tanaman rakyat merupakan faktor yang menunjang keberhasilan pelaksanaan pembangunan hutan tanaman rakyat yang dijalankan selama ini. Secara keseluruhan, partisipasi masyarakat pada pembangunan hutan tanaman rakyat ini tergolong sedang. Hal ini menggambarkan bahwa dalam kegiatan pembangunan hutan tanaman rakyat yang dilaksanakan selama ini masyarakat belum terlibat secara penuh pada semua tahapan kegiatan. Menurut Winarto (2003) masyarakat tergerak untuk berpartisipasi jika partisipasi itu memberikan manfaat langsung kepada masyarakat yang bersangkutan atau manfaat yang diperoleh melalui partisipasi itudapat memenuhi kepentingan masyarakat. Masyarakat pada umumnya mempunyai keinginan untuk berpartisipasi dalam kegiatan pembangunan hutan tanaman rakyat, karena masyarakat menilai bahwa pembangunan hutan tanaman rakyat akan memberikan manfaat bagi mereka sendiri dan bagi penduduk desaumumnya, baik manfaat yang secara langsung maupun manfaat yang secara tidak langsung dirasakan.

Dalam pembangunan hutan tanaman rakyat ini tidak semua kegiatan membuka kesempatan kepada masyarakat untuk berpartisipasi. Kesempatan untuk berpartisipasi diberikan hanya kepada sebagian masyarakat. Misalnya pada kegiatan penyusunan rencana dan program, kesempatan berpartisipasi hanya diberikan kepada tokoh masyarakat seperti ketua gapoktan, kepala desa, dan pendamping yang merupakan anggota kelompok tani hutan. Hal ini sesuai Winarto (2003) yang menyatakan bahwa kesempatan, kemampuan dan kemauan mutlak harus ada dalam keseimbangan. Apabila salah satu faktor tersebut tidak tercakup maka partisipasi tidak akan sempurna. Partisipasi masyarakat pada kegiatan pembangunan hutan tanaman rakyat terjalin pada semua tahapan kegiatan, partisipasi dalam kegiatan perencanaan, partisipasi dalam aktivitas kelompok tani hutan rakyat, partisipasi dalam pelaksanaan kegiatan hutan rakyat dan partisipasi dalam pengamanan. Keempat komponen partisipasi tersebut di atas mempunyai keterkaitan hubungan satu sama lain. Artinya keterlibatan dalam perencanaan akan berkaitan dengan aktivitas kelompok tani, selanjutnya berkaitan dengan pelaksanaan yangpada akhirnya berkaitan dengan kegiatan pengamanan.

Partisipasi masyarakat yang diukur dalam penelitian ini adalah partisipasi masyarakat dalam perencanaan; partisipasi masyarakat dalam aktivitas kelompok tani hutan; partisipasi masyarakat dalam pembibitan, penanaman, pemeliharaan; dan partisipasi dalam pengamanan, pemecahan masalah, dan pemasaran. Partisipasi masyarakat dalam perencanaan tergolong rendah $(50,3 \%)$. Tahap awal yang merupakan bagian perencanaan antara lain pengukuran areal lokasi HTR, penentuan jenis tanaman, dan penyusunan rencana dan program hutan tanaman rakyat. Masyarakat tidak dilibatkan dalam penentuan jenis tanaman, akan tetapi aturan yang telah ada dalam P.83/MENLHK/SETJEN/KUM.1/10/2016 tentang perhutanan sosial, sesuai dengan tanaman yang masyarakat tanam selama ini. Untuk penyusunan rencana dan program hutan tanaman rakyat, mereka sampai saat ini belum menyusun rencana kerja tahunan dan rencana kerja umum yang merupakan kewajiban dari pemegang ijin HTR. Perencanaan merupakan dasar kegiatan yang mengarahkan dan menuntun orang untuk melakukan kegiatan sesuai dengan prosedur yang telah ditentukan guna mencapai tujuan yang diinginkan.

Untuk partisipasi responden dalam aktivitas kelompok tani hutan tergolong sedang (76,8\%). dalam pembentukan kelompok tani sistemnya berbeda-beda untuk masing-masing kelompok.Ada yang pembentukan kelompok taninya melibatkan seluruh petani, ada yang dengan perwakilan dan ada pula yang hanya melibatkan tokoh-tokoh masyarakat. Dalam wawancara, terdapat responden yang tidak mengetahui nama kelompok tani mereka dikarenakan dalam pembuatan kelompok tani hanya melibatkan perwakilan saja.

Walaupun mereka setuju dengan peran KTH, namun mereka merasa belum saling mengenal antar satu anggota dengan anggota yang lain. Hal ini wajar dikarenakan mengingat kelembagaan KTH yang mereka bentuk baru. Selain itu, mereka juga beranggapan bahwa keaktifan setiap anggota kelompok dalam kelompoknya sangat rendah. KTH selama ini baru berperan dalam proses pengajuan ijin dan dapat dibilang bahwa yang berperan hanya anggota tertentu saja dan ketua nya, sedangkan dalam kegiatan lainnya peran KTH belum terilihat. Di Desa Sinar Ogan, Budi Lestari, Srikaton, Jati Indah, dan Jati Baru, frekuensi pertemuan antar anggota kelompok maupun antar kelompok sangat tinggi pada saat proses pengajuan baru berjalan. Namun begitu ijin telah keluar, frekuensi pertemuan tersebut menurun dengan drastis bahkan hampir tidak pernah dilakukan lagi.Meskipun demikian dari petani hutan rakyat yang menjadi responden, apabila ada undangan pertemuan 
kelompoktani dipastikan akan datang memenuhi undangan tersebut.

Partisipasi dalam hal pembibitan, penanaman, pemeliharaan tergolong tinggi $(68,4 \%)$ dibandingkan dengan partisipasi lainnya. Hal tersebut dikarenakan kegiatan tersebut telah dilaksanakan oleh masyarakat jauh sebelum IUPHHK-HTR keluar. Mereka telah melakukan pembibitan, penanaman, serta pemeliharaan di lahan mereka. Sedangkan partisipasi dalam pengamanan, pemecahan masalah, dan pemsaran hasil menunjukkan nilai yang terendah dibandingkan dengan nilai partisipasi kegiatan lainnya $(61,1)$. Sampai saat ini belum terdapat aktivitas pemasaran hasil dikarenakan masyarakat belum melakukan pemanenan.

\section{B. Faktor-faktor yang mempengaruhi tingkat partisipasi masyarakat dalam implementasi HTR}

Untuk melihat pengaruh variabel bebas (X) terhadap variabel tak bebas (partisipasi masyarakat pada kegiatan pembangunan hutan tanaman rakyat) dilakukan dengan menggunakan analisis regresi berganda. Variabel yang dianalisis mencakup faktor-faktor partisipasi yang dianggap bisa mempengaruhi partisipasi masyarakat pada pembangunan hutan tanaman rakyat. Variabel tersebut adalah manfaat (X1), jenis tanaman (X2), persyaratan perijinan (X3), proses perijinan (X4), pewarisan (X5), hak dan kewajiban (X6), kelembagaan (X7), Sosialisasi (X8), tenaga pendamping (X9), dan dukungan (X10).

Tabel 1. Analisis regresi linier berganda faktor-faktor yang mempengaruhi partisipasi masyarakat terhadap pembangunan HTR

\begin{tabular}{lcc}
\hline \multicolumn{1}{c}{ Variabel Bebas } & Koefisien Regresi & Pvalue \\
\hline Manfaat $\left(\mathrm{X}_{1}\right)$ & 0,850 & 0,015 \\
Jenis Tanaman $\left(\mathrm{X}_{2}\right)$ & $-0,214$ & 0,874 \\
Persyaratan perijinan $\left(\mathrm{X}_{3}\right)$ & 0,196 & 0,627 \\
Proses perijinan $\left(\mathrm{X}_{4}\right)$ & 0,080 & 0,806 \\
Pewarisan $\left(\mathrm{X}_{5}\right)$ & 0,305 & 0,499 \\
Hak dan kewajiban $\left(\mathrm{X}_{6}\right)$ & 0,613 & 0,313 \\
Kelembagaan $\left(\mathrm{X}_{7}\right)$ & 0,415 & 0,064 \\
Sosialisasi $\left(\mathrm{X}_{8}\right)$ & 0,579 & 0,011 \\
Tenaga Pendamping $\left(\mathrm{X}_{9}\right)$ & 0,715 & 0,000 \\
Dukungan $\left(\mathrm{X}_{10}\right)$ & 0,648 & 0,009 \\
Konstanta & 0,045 & 0,997 \\
F hitung & 9,727 & 0,000 \\
$\mathrm{R}$ & 0,733 & \\
$\mathrm{R}$ Square & 0,537 & \\
\hline
\end{tabular}

Sumber : Hasil Penelitian (2017)

Berdasarkan uji analisa pada tabel 1 diatas diperoleh nilai koefisien determinasi (R2) yang diperoleh sebesar 0,537. Hal ini menunjukkan bahwa model regresi yang diperoleh menjelaskan keragaman data yang diteliti sebanyak $53 \%$. Sedangkan sisanya $47 \%$ diterangkan oleh variabel lain yang tidak termasuk dalam model ini. Dari uji analisa, diperoleh nilai Fhitung sebesar 9,723 dengan nilai probabilitas $(\operatorname{sig})=0,000$. Sedangkan nilai Ftabel sebesar 1,94. Oleh karena Fhitung $(9,727)>$ Ftabel $(1,94)$ dan nilai probabilitas (sig) lebih kecil dari nilai probabilitas 0,05, maka faktor-faktor persepsi secara bersamasama berpengaruh terhadap partisipasi.

Seberapa besar pengaruh variabel bebas terhadap variabel tak bebas (partisipasi) dilakukan analisis lanjutan dengan tahapan memasukkan semua variabel bebas, kemudian dilakukan analisis dan variabel yang tidak layak masuk dalam regresi dikeluarkan satu persatu. Berdasarkan hasil uji statistik pada tabel 2, tidak semua variabel bebas menunjukkan peran yang nyata sebagai penduga variabel tak bebas. Hasilnya adalah variabel jenis tanaman (X2), persyaratan perijinan (X3), proses perijinan (X4), Pewarisan (X5), hak dan kewajiban (X6), dan kelembagaan (X7) dinyatakan sebagai variabel bebas yang tidak berpengaruh nyata terhadap partisipasi responden. Sedangkan untuk variabel manfaat (X1), sosialisasi (X8), tenaga pendamping (X9), dan dukungan (X10) dinyatakan sebagai variabel bebas yang berpengaruh nyata terhadap partisipasi responden terhadap pembangunan HTR. Oleh karena itu didapatkan persamaan sebagai berikut : $\mathrm{Y}=0,045+0,85 \mathrm{X} 1+0,579 \mathrm{X} 8+0,715 \mathrm{X} 9+0,648 \mathrm{X} 10$

$\mathrm{Y}=$ partisipasi masyarakat

$\mathrm{X} 1=$ manfaat

$\mathrm{X} 8=$ sosialisasi

X9 = tenaga pendamping

$\mathrm{X} 10=$ dukungan

Besarnya pengaruh faktor-faktor partisipasi sebagai variabel bebas terhadap partisipasi masyarakat terhadap pembangunan hutan tanaman rakyat sebagai variabel tak bebas dijelaskan sebagai berikut :

(1) Pengaruh Manfaat terhadap Tingkat Partisipasi Berdasarkan hasil uji statistik, manfaat yang diterima oleh masyarakat berpengaruh secara nyata terhadap tingkat partisipasi masyarakat dalam pem-bangunan hutan tanaman rakyat. Masyarakat merasa tenteram dengan adanya IUPHHK-HTR dikarenakan kenyamanan dan keamanan dalam mengelola lahan. Perkembangan kegiatan HTR di lokasi penelitian merupakan tahap awal karena masyarakat baru mendapatkan ijin usaha pengelolaan hutan-hutan tanaman rakyat pada tanggal 1 Maret 2017 yang lalu sehingga manfaat yang dimaksud dalam penelitian ini lebih ditujukan pada harapan masyarakat dengan mengikuti program pembangunan hutan tanaman rakyat. Namun demikian manfaat yang saat ini sudah dirasakanolehmasyarakatadalahmengenaikepastian status lahan yang mereka miliki. Dengan adanya kepastian status lahan, maka status masyarakat yang 
tadinya bisa dibilang sebagai perambah, kini berubah menjadi pengelola hutan. Selain itu, dengan adanya program pembangunan Hutan Tanaman Rakyat ini masyarakat berharap bantuan seperti pemberian bibit, pemberian pupuk, pemberian pelatihan untuk meningkatkan hasil panen dapat mereka peroleh. Dengan alasan tersebut manfaat yang diterima oleh masyarakat mempengaruhi partisipasi masyarakat dalam pembangunan hutan tanaman rakyat.

(2) Pengaruh Jenis Tanaman terhadap Tingkat Partisipasi

Berdasarkan hasil uji statistik, jenis tanaman tidak berpengaruh secara nyata terhadap tingkat partisipasi masyarakat dalam pembangunan hutan tanaman rakyat. Kenyataannya, masyarakat tetap dapat menikmati hasil ketika jenis tanaman diatur oleh Kementerian Lingkungan Hidup. Selain itu, tanaman yang telah ditetapkan dalam P.83/MENLHK/ SETJEN/KUM.1/10/2016 tentang perhutanan sosial, tidak bertentangan dengan keinginan masyarakat. Dengan kata lain jenis tanaman yang telah diatur sesuai dengan harapan masyarakat.

Jenis tanaman pokok yang dapat dikembangkan untuk pembangunan usaha pemanfaatan hasil hutan kayu HTR terdiri dari: a. tanaman sejenis; atau b. tanaman berbagai jenis. Jenis tanaman pokok sejenis sebagaimana dimaksud adalah tanaman hutan berkayu yang hanya terdiri satu jenis (species) dan varietasnya. Jenis tanaman pokok berbagai jenis sebagaimana dimaksud adalah tanaman hutan berkayu yang dikombinasikan dengan tanaman budidaya tahunan yang berkayu antara lain karet, tanaman berbuah, bergetah dan pohonpenghasil pangan dan energi. Tanaman budidaya tahunan paling luas $40 \%$ (empat puluh persen) dari areal kerja dan tidak didominasi oleh satu jenis tanaman. Di lokasi penelitian seperti di Desa Budi Lestari, lahan di dominasi tanaman karet, akasia, sawit, dan sengon yang diselang seling dengan acasia. Di Desa Sinar Ogan lahan ditanami karet, acasia, sawit, palawija. Di Desa Jati Baru lahan ditanami karet,acasia, sawit, dan palawija. Desa Srikaton seluruh areal sudah dimanfaatkan dengan ditanami karet 80\% sisanya ditanami sengon, acasia, singkong, jagung, dan padi. Sedangkan Desa Jati Indah lahannya ditanami karet, jati, dan acasia.

Namun, bila dilihat dari jenis tanaman yang masyarakat usahakan di lahan hutan tanaman rakyat, dalam jangka waktu 5 tahun belum dapat memenuhi kebutuhan industri kayu karena produksi yang dihasilkan sebagian besar adalah getah karet, dan untuk acasia serta sengon sebagian besar masih berumur sekitar 2 sampai 3 tahun.

(3) Pengaruh persyaratan perijinan terhadap Tingkat Partisipasi

Berdasarkan hasil uji statistik, persyaratan perijinan tidak berpengaruh secara nyata terhadap tingkat partisipasi masyarakat dalam pembangunan hutan tanaman rakyat. Dikarenakan berdasarkan hasil wawancara persyaratan perijinan menurut responden tergolong mudah dikarenakan mereka hanya diminta untuk mengumpulkan kartu identitas diri seperti Kartu Tanda Penduduk (KTP). Namun pada beberapa desa seperti Desa Srikaton dan Jati Indah, masyarakat berpendapat bahwa masyarakat yang merupakan pendatang agak dipersulit persyaratannya, hal tersebut dikarenakan terjadinya migrasi pendatang sehingga sebagian penduduk tidak mempunyai surat keterangan ijin tinggal. Hal ini mengacaukan administrasi desa. Dengan demikian perlu dilakukan penguatan kelembagaan pemerintahan desa dan pengawasan dari institusi di atasnya.

\section{(4) Pengaruh Proses perijinan terhadap Tingkat Partisipasi}

Dari hasil wawancara, meskipun proses perijinannya yang tidak berbelit-belit dan tidak membutuhkannya biaya yang besar, namun waktu yang dibutuhkan agar perijinan keluar tergolong lama. Proses dari waktu pengajuan sampai diterbitkannya SK IUPHHK-HTR membutuhkan waktu kurang lebih 3 tahun. Berdasarkan hasil uji statistik, proses perijinan tidak berpengaruh secara nyata terhadap tingkat partisipasi masyarakat dalam pembangunan hutan tanaman rakyat. Proses yang lama tidak mempengaruhi tinggi rendahnya tingkat partisipasi masyarakat dikarenakan ada atau tidaknya ijin IUPHHK-HTR tersebut, masyarakat tetap dapat memanfaatkan lahan.

Walaupun persyaratan bagi masyarakat yang ingin mengajukan ijin pemanfaatan HTR (IUPHHKHTR) mudah dipenuhi, waktu yang dibutuhkan agar ijin IUPHHK-HTR keluar tergolong lama. Usulan pencadangan HTR telah dilakukan mulai tahun 2014, dengan rincian sebagai berikut :

1) Surat Bupati Lampung Selatan nomor 522/2469/III.13/02/2014 tanggal 14 Juni 2014 menyampaikan usulan pencadangan HTR yang dimohon Gapoktan Maju (Desa Budi Lestari), Gemah Ripah (Desa Sinar Ogan), dan Karya Mudah (Desa Jati Baru).

2) Surat Bupati Lampung Selatan nomor 522/3911/ III.13/02/2014 tanggal 5 November 2014, menyampaikan usulan pencadangan areal HTR yang dimohon Gapoktan Jaya Abadi (Desa Srikaton) dan Subur (Desa Jati Indah).

Kelima Desa tersebut, baru akhirnya mendapatkan ijin IUPHHK-HTR pada bulan Maret 2017 dan diserahkan melalui Kepala Dinas Kehutanan Provinsi Lampung. Namun SK IUPHHK-HTR yang diberikan masih bersifat sementara karena belum merupakan SK asli hanya SK salinan. Rencananya 
SK IUPHHK-HTR asli akan diberikan langsung oleh Presiden Republik Indonesia pada bulan April 2017. Namun sampai saat ini, SK asli tersebut belum juga diserahkan sehingga masyarakat hanya memegang SK salinan saja.

\section{(5) Pengaruh Pewarisan terhadap Tingkat Partisipasi}

Sesuai dengan Peraturan Menteri Lingkungan Hidup dan Kehutanan Republik Indonesia Nomor P. 83.MENLHK/SETJEN/KUM.1/10/2016 tentang perhutanan sosial, IUPHHK-HTR berlaku untuk jangka 35 tahun dan tidak dapat diwariskan. Dengan adanya ketentuan bahwa ijin IUPHHK HTR tidak dapat diwariskan, maka ketika pemegang ijin telah meninggal dunia, ijin harus dikembalikan kepada negara. Seseorang hanya dapat mengelola lahan tersebut sampai orang tersebut meninggal dunia walaupun ijin tersebut setelah 35 tahun dapat diperpanjang lagi. SK IUPHHK-HTR yang dipegang oleh masingmasing ketua gapoktan, aturannya sama dengan peraturan yang termuat dalam P.83/MENLHK/ SETJEN/KUM.1/10/2016 tentang perhutanan sosial, dimana IUPHHK-HTR tidak dapat diwariskan. Hasil wawancara menunjukan bahwa seluruh responden kurang setuju bahwa lahan HTR tidak dapat diwariskan dikarenakan selama ini mereka telah menggarap lahan tersebut turun menurun dalam jangka waktu yang lama. Sampai wawancara dilakukan, responden tidak mengetahui bahwa aturan dalam P.83/MENLHK/SETJEN/KUM.1/10/2016 dan juga SK IUPHHK-HTR adalah tidak dapat diwariskan. Hal ini dikarenakan SK dipegang oleh ketua gapoktan dan belum ada pertemuan kelompok lanjutan setelah ijin tersebut keluar dan SK diberikan kepada ketua gapoktan. Selain itu sosialisasi dilakukan dengan hanya mengundang ketua gapoktan saja, sehingga informasi belum sampai kepada masyarakat.

Berdasarkan hasil uji statistik, pewarisan tidak berpengaruh secara nyata terhadap tingkat partisipasi masyarakat dalam pembangunan hutan tanaman rakyat. Hal ini mendukung pernyataan di atas, bahwa masyarakat belum mengetahui aturan yang sesungguhnya mengenai pewarisan. Hal tersebut juga disebabkan oleh kurangnya intensitas penyuluhan dan keterbatasan informasi yang didapatkan oleh masyarakat.

\section{(6) Pengaruh Hak dan Kewajiban terhadap Tingkat Partisipasi}

Hak dan kewajiban dari kelompok tani hutan telah tertuang dalam SK yang diberikan kepada masingmasing gapoktan pada bulan Maret 2017. Hak dan kewajiban yang tertuang dalam SK IUPHHK-HTR sama dengan dalam P.83/MENLHK/SETJEN/ KUM.1/10/2016 tentang perhutanan sosial. Kewajiban dari pemegang ijin IUPHHK-HTR antara lain menjaga arealnya dari perusakan dan pencemaran, memberi tanda batas areal kerjanya, menyusun RKU (Rencana Kerja Usaha), dan RKT (Rencana Kerja Tahunan), melakukan penanaman dan pemeliharaan hutan di areal kerjanya, melakukan tata usaha hasil hutan, membayar provisi sumber daya hutan, mempertahankan fungsi hutan, dan melaksanakan perlindungan hutan.

Berdasarkan hasil uji statistik, hak dan kewajiban tidak berpengaruh secara nyata terhadap tingkat partisipasi masyarakat dalam pembangunan hutan tanaman rakyat. Hal ini dikarenakan pemahaman masyarakat akan manfaat dari hutan tanaman rakyat tinggi. Hal tersebut dapat dijelaskan bahwa masyarakat menyadari manfaat positif kepada kedua belah pihak, baik negara maupun masyarakat. Sehingga urgensi akan hak dan kewajiban dirasakan tidak berpengaruh nyata terhadap tingkat partisipasi.

\section{(7) Pengaruh Kelembagaan terhadap Tingkat Partisipasi}

Kelompok tani dibuat dengan tujuan untuk memudahkan pengurusan administrasi dalam pengajuan ijin HTR, memudahkan transfer informasi mengenai HTR, dan memudahkan administrasi pengajuan pinjam dana bergulir untuk pembangunan HTR nantinya. Yang terjadi di lapangan adalah bahwa kelembagaan HTR di daerah penelitian merupakan kelembagaan baru yang sengaja dibuat demi kepentingan pelaksanaan HTR.

Walaupun mereka setuju dengan peran KTH, namun mereka merasa belum saling mengenal antar satu anggota dengan anggota yang lain. Hal ini wajar dikarenakan mengingat kelembagaan KTH yang mereka bentuk baru. Selain itu, mereka juga beranggapan bahwa keaktifan setiap anggota kelompok dalam kelompoknya sangat rendah. KTH selama ini baru berperan dalam proses pengajuan ijin dan dapat dibilang bahwa yang berperan hanya anggota tertentu saja dan ketua nya, sedangkan dalam kegiatan lainnya peran KTH belum terilihat. Di Desa Sinar Ogan, Budi Lestari, Srikaton, Jati Indah, dan Jati Baru, frekuensi pertemuan antar anggota kelompok maupun antar kelompok sangat tinggi pada saat proses pengajuan baru berjalan. Namun begitu ijin telah keluar, frekuensi pertemuan tersebut menurun dengan drastis bahkan hampir tidak pernah dilakukan lagi.

Berdasarkan hasil uji statistik, kelembagaan tidak berpengaruh secara nyata terhadap tingkat partisipasi masyarakat dalam pembangunan hutan tanaman rakyat. Dikarenakan pada lokasi penelitian, 
responden tidak merasakan pengaruh langsung terhadap manfaat lembaga tersebut. Karena pada kenyataannya, mayoritas responden menggarap lahannya secara individu bukan secara kelompok.

(8) Pengaruh Sosialisasi terhadap Tingkat Partisipasi Masyarakat beranggapan bahwa frekuensi kegiatan sosialisasi tentang HTR yang selama ini dilakukan sudah cukup walaupun mereka mengatakan bahwa penyuluhan yang dilakukan secara langsung hanya untuk perwakilan saja, sedangkan informasi sosialisasi selanjutnya diberikan dalam pertemuan kelompok tani. Namun, mereka beranggapan bahwa materi penyuluhan yang diberikan selama ini belum sesuai dengan kebutuhan masyarakat dan menunjang program HTR. Selama ini sosialisasi yang diberikan hanya sebatas pengertian HTR, hak dan kewajiban masyarakat sebagai pemegang ijin, sedangkan yang diinginkan masyarakat adalah lebih ke usaha dan akses pasar nantinya.

Berdasarkan hasil uji statistik, sosialisasi berpengaruh secara nyata terhadap tingkat partisipasi masyarakat dalam pembangunan hutan tanaman rakyat. Partisipasi masyarakat terhadap program HTR rendah dikarenakan kurangnya intensitas penyuluhan, hal tersebut dikarenakan sosialisasi yang diberikan terhadap mereka kurang. Hal ini juga disebabkan karena materi sosialisasi yang belum sesuai dengan keinginan masyarakat dan metode sosialisasi yang dilakukan. Masyarakat ingin diadakan studi banding ke tempat kelompok tani lain yang sudah berhasil mengembangkan usaha dan memiliki askses pasar sehinggan mereka dapat mencontohnya.

\section{(9) Pengaruh Tenaga Pendamping terhadap} Tingkat Partisipasi

Pendampingan merupakan hak yang diperoleh setiap pemegang ijin HTR. Hal ini sesuai dengan P.83/MENLHK/SETJEN/KUM.1/10/2016 tentang perhutanan sosial. Pendampingan juga dibutuhkan untuk menunjang kegiatan HTR. Pendampingan HTR dilakukan oleh penyuluh kehutanan dan pihak dari KPHP Gedong Wani sendiri.

Menurut Rosalia dan Ratnasari (2016), kegiatan pendampingan masyarakat/ fasilitasi bertujuan meningkatkan kemampuan masyarakat setempat dalam mengelola organisasi kelompok, membimbing masyarakat mengajukan permohonan izin sesuai ketentuan yang berlaku, meningkatkan kemampuan masyarakat setempat dalam menyusun rencana kerja pemanfaatan hutan, meningkatkan kemampuan masyarakat setempat dalam melaksanakan budidaya hutan melalui pengembangan teknologi tepat guna dan peningkatan nilai tambah hasil hutan, meningkatkan kualitas sumberdaya manusia masyarakat setempat melalui pengembangan pengetahuan, kemampuan dan keterampilan, memberikan informasi pasar dan modal dalam meningkatkan daya saing dan akses masyarakat setempat terhadap pasar dan modal, dan meningkatkan kemampuan masyarakat setempat dalam mengembangkan usaha pemanfaatan hutan dan hasil hutan.

Berdasarkan hasil uji statistik, tenaga pendamping berpengaruh secara nyata terhadap tingkat partisipasi masyarakat dalam pembangunan hutan tanaman rakyat. Pada lokasi penelitian dikarenakan kurangnya tenaga pendamping dan rendahnya intensitas sosialisasi menyebabkan partisipasi masyarakat terhadap program pembangunan HTR rendah. Saat ini, pendampingan yang berjalan baru bersifat teknis. Untuk pendampingan yang bersifat non teknis seperti penguatan kelembagaan masih sangat kurang. Padahal penguatan kelembagaan merupakan faktor penting dalam menyiapkan masyarakat untuk mengelola HTR (Hakim, 2009). Hal ini perlu diperhatikan, karena pendampingan penguatan kelembagaan dapat membangun masyarakat yang mandiri dalam mengelola hutan.

(10) Pengaruh Dukungan terhadap Tingkat Partisipasi

Responden berpendapat bahwa dukungan yang diberikan baik dari pemerintah desa maupun Dinas Kehutanan dan KPHP Gedong Wani tidak dirasakan oleh semua responden dan hanya dirasakan manfaatnya oleh elite kelompok tani. Dukungan dalam penguatan kelembagaan dirasakan rendah dikarenakan dengan dibentuknya kelompok tani manfaat tidak dapat dirasakan langsung oleh masyarakat. Hal tersebut dikarenakan 1) dalam proses pengolahan lahan dilakukan secara individu bukan kelompok, 2) tidak ada koordinasi antara kelompok tani, dan 3) mayoritas kelompok tani dikuasai oleh satu anggota keluarga. Sehingga hanya segelintir orang yang merasakan manfaat dari dukungan penguatan kelembagaan tersebut.

Dukungan dalam penguatan kapasitas masyarakat juga dirasakan kurang karena kurangnya kegiatan pelatihan, studi banding dan sosialisasi sehingga tidak ada manfaat yang masyarakat rasakan. Bentuk dukungan yang diberikan sejauh ini hanyalah fasilitas pengurus izin, pendampingan dan pembuatan aturan main kelompok, namun intensitasnya masih rendah.

Berdasarkan hasil uji statistik, dukungan berpengaruh secara nyata terhadap tingkat partisipasi masyarakat dalam pembangunan hutan tanaman rakyat. Dikarenakan kurangnya dukungan yang diberikan, baik dari pihak pemerintah maupun non pemerintahan seperti sosialisasi dan pendampingan maka tingkat partisipasi dalam pembangunan hutan tanaman rakyat rendah. 


\section{Strategi implementasi kebijakan HTR}

Partisipasi masyarakat KPH Gedong Wani terhadap pembangunan HTR tergolong sedang, artinya adalah bahwa masyarakat bisa saja mendukung atau bisa menghambat kegiatan-kegiatan yang dapat menyukseskan pembangunan HTR. Oleh karena itu diperlukan strategi yang dapat meningkatkan partisipasi masyarakat dalam pembangunan HTR dimana nantinya dengan adanya partisipasi yang tinggi, masyarakat dapat ikut menyukseskan pembangunan HTR dan yang terpenting adalah dapat memperbaiki kawasan hutan yang sudah mulai hilang fungsinya.

Kondisi internal program HTR di KPH Gedong Wani yang terdiri dari kekuatan dan kelemahan yang dihitung berdasarkan rating dan bobot menggunakan matrik IFAS (internal strategic factors analysis summary) menghasilkan 6 faktor kekuatan dalam pembangunan HTR, yaitu: 1) sudah terbentuknya kelompok tani, 2) adanya SK-IUPHHK HTR, 3) adanya dukungan dari aparat desa, 4) adanya penyuluh yang kompeten, 5) terbentuknya KPH yang memfasilitasi kegiatan HTR, dan 6) sudah adanya lahan yang dimanfaatkan secara agoroforestry; dan 6 faktor kelemahan, yaitu 1) rendahnya tingkat pendidikan masyarakat di dalam kawasan, 2) kurangnya tenaga pendamping, 3) kelembagaan kelompok tani yang kurang berjalan dengan optimal, 4) masyarakat kurang memahami mengenai hak dan kewajiban sebagai pemegang ijin HTR, 5) kurang adanya sinergitas antara masyarakat dengan Dinas Kehutanan, dan 6) terdapatnya pemukiman di lokasi HTR. Hasil nilai pembobotan memperlihatkan bahwa kekuatan utama dengan nilai tertimbang terbesar adalah adanya SK IUPHHK-HTR. Gabungan kelompok tani yang terdapat di 5 desa, yaitu Desa Sinar Ogan, Desa Trimulyo, Desa
Budi Lestari, Desa Jati Indah, dan Desa Jati Baru telah menerima SK IUPHHK-HTR pada bulan Maret 2017. Sedangkan faktor yang menjadi kelemahan antara lain kurangnya tenaga pendamping, kelembagaan kelompok tani yang kurang berjalan dengan optimal, dan masyarakat kurang memahami mengenai hak dan kewajiban sebagai pemegang ijin HTR, dimana masing-masing skor dari faktor tersebut sebesar 0,4.

Kondisi eksternal program HTR di KPH Gedong Wani yang terdiri dari peluang dan ancaman yang dihitung berdasarkan rating dan bobot menggunakan EFAS (external strategic factors analysis summary) menemukan 4 faktor peluang, yaitu 1) terbentuknya lapangan kerja dari usaha sektor kecil dan menengah, 2) kerjasama dengan multipihak, 3) bertambahnya pendapatan asli daerah, dan 4) ketersediaan kayu tetap terjaga; dan 5 faktor ancaman, yaitu 1) pemukiman liar semakin bertambah, 2) kondisi hutan semakin kritis, 3) belum adanya pangsa pasar yang jelas, 4) terjadi pemindah kuasaan atas lahan, dan 5) migrasi penduduk yang besar. Hasil nilai pembobotan memperlihatkan bahwa faktor yang menjadi peluang utama adalah terbentuknya lapangan kerja dari usaha sektor kecil dan menengah dan ketersediaan kayu tetap terjaga, dengan nilai 0,52 masing-masing faktor. Sedangkan ancaman utama adanya program HTR ini adalah pemukiman liar semakin bertambah dengan nilai 0,52.Berdasarkan analisis SWOT terhadap evaluasi faktor internal (IFAS) serta evaluasi terhadap faktor eksternal (EFAS), maka kecenderungan posisi masyarakat dalam lokasi penelitian terhadap implementasi kebijakan HTR berada pada kuadran IV $(0,27,-0,22)$ yang berarti program terkini lebih diarahkan pada diversifikasi strategi yang menggunakan kekuatan untuk mengatasi ancaman.

Tabel 2. Analisis SWOT berdasarkan evaluasi faktor internal dan eksternal

\begin{tabular}{|c|c|c|}
\hline EFAS & $\begin{array}{l}\text { Kekuatan (S) } \\
\text { 1.Sudah terbentuknya kelompok tani } \\
\text { 2.Adanya SK IUPHHK-HTR } \\
\text { 3.Adanya dukungan dari aparat desa } \\
\text { 4.Adanya penyuluh yang kompeten } \\
\text { 5.Terbentuknya KPH yang memfasilitasi } \\
\text { kegiatan HTR } \\
\text { 6.Sudah adanya lahan yang dimanfaatkan } \\
\text { secara agoroforestry }\end{array}$ & 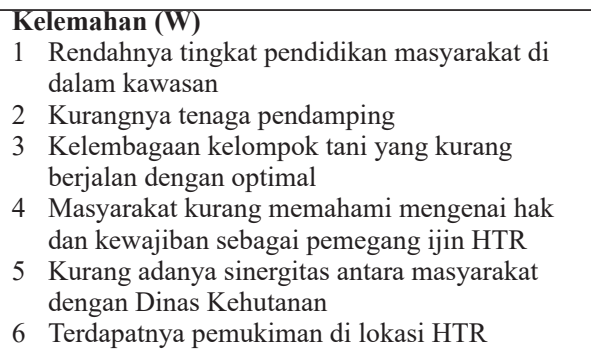 \\
\hline $\begin{array}{l}\text { Peluang (O) } \\
1 \text { Terbentuknya lapangan kerja } \\
\text { dari usaha sektor kecil dan } \\
\text { menengah } \\
2 \text { Kerjasama dengan multipihak } \\
3 \text { Bertambahnya pendapatan asli } \\
\text { daerah } \\
4 \text { Ketersediaan kayu tetap } \\
\text { terjaga }\end{array}$ & $\begin{array}{l}\text { STRATEGISO } \\
\text { a Mengembangkan usaha dengan } \\
\text { bekerja sama dengan multipihak } \\
(\mathrm{S} 3, \mathrm{~S} 4, \mathrm{~S} 5, \mathrm{O} 1, \mathrm{O} 2, \mathrm{O} 3) \\
\text { b Pembentukan dan pengefektifan fungsi } \\
\text { koperasi }(\mathrm{S} 1, \mathrm{~S} 5, \mathrm{O} 1, \mathrm{O} 3, \mathrm{O} 4)\end{array}$ & $\begin{array}{l}\text { STRATEGI WO } \\
\text { a Penguatan kelembagaan KTH }(\mathrm{W} 2, \mathrm{~W} 3, \mathrm{~W} 4, \mathrm{~W} 6 \text {, } \\
\text { O4) } \\
\text { b Peningkatan kualitas dan kuantitas penyuluh } \\
(\mathrm{W} 1, \mathrm{~W} 2, \mathrm{~W} 3, \mathrm{~W} 4, \mathrm{~W} 6, \mathrm{O} 1, \mathrm{O} 2, \mathrm{O} 3, \mathrm{O} 4)\end{array}$ \\
\hline $\begin{array}{l}\text { Ancaman (T) } \\
1 \text { Pemukiman liar semakin } \\
\text { bertambah } \\
2 \text { Kondisi hutan semakin kritis } \\
3 \text { Belum adanya pangsa pasar } \\
\text { yang jelas } \\
4 \text { Terjadi pemindah kuasaan atas } \\
\text { lahan } \\
5 \text { Migrasi penduduk yang besar }\end{array}$ & $\begin{array}{l}\text { STRATEGI ST } \\
\text { a Pemanfaatan potensi lahan yang } \\
\text { tersedia }(\mathrm{S} 1, \mathrm{~S} 2, \mathrm{~T} 2, \mathrm{~T} 4) \\
\text { b Menerapkan pola SFM }(\text { Suistanable } \\
\text { Forest Management) }(\mathrm{S} 6, \mathrm{~T} 2)\end{array}$ & $\begin{array}{l}\text { STRATEGI WT } \\
\text { a Menjamin kepastian usaha dengan melibatkan } \\
\text { berbagai pihak }(\mathrm{W} 5, \mathrm{~T} 3) \\
\text { b Dukungan pendanaan dari multipihak (W5,T3) } \\
\text { c Peningkatan SDM petani melalui sekolah lapang } \\
\text { dan lapang }(\mathrm{W} 1, \mathrm{~W} 4, \mathrm{~T} 2, \mathrm{~T} 4)\end{array}$ \\
\hline
\end{tabular}


Sintesis unsur-unsur SWOT dengan skor tertinggi menghasilkan alternatif strategi. Analisis SWOT strategi implementasi kebijakan KPH Gedong Wani berdasarkan evaluasi faktor internal dan eksternal disajikan pada Tabel 2. Berdasarkan QSPM, diperoleh 2 strategi SO : Mengembangkan usaha dengan bekerja sama dengan multipihak dan pembentukan dan pengefektifan fungsi koperasi, 2 strategi WO: penguatan kelembagaan $\mathrm{KTH}$ dan peningkatan kualitas dan kuantitas penyuluh, 2 strategi ST, yaitu pemanfaatan potensi lahan yang tersedia dan menerapakan pola SFM (Suistanable Forest Management), sedangkan terdapat 3 strategi WT yaitu menjamin kepastian usaha dengan melibatkan berbagai pihak, dukungan pendanaan dari multipihak, dan peningkatan SDM petani melalui sekolah lapang dan lapang.

Strategi SO bertujuan agar pemegang IUPHHKHTR dapat mandiri dalam mengelola lahan yang telah diberikan ijin. Dengan adanya pembentukan koperasi, ditujukan untuk menyejahterakan anggotanya serta ikut membangun tatanan perekonomian nasional. Dengan adanya masyarakat mandiri, diharapakan mereka juga mampu untuk bekerja sama dengan multipihak sehingga dapat meningkatkan taraf hidup masyarakat. Koperasi ini juga merupakan wadah pertukaran informasi dan saling mengenal anggota satu sama lain, dimana permasalahan mengenai kelompok tani hutan di ke lima desa pemegang IUPHHK-HTR adalah sudah terbentuknya kelompok tani tetapi frekuensi pertemuan mereka berkurang dan juga informasi mengenai HTR tidak sampai pada masyarakat hanya segelintir kelompok elit saja seperti ketua nya saja.

Strategi WO bertujuan untuk mengatasi kurangnya tenaga pendamping. Tenaga pendamping berperan sebagai fasilitator dan motivator bagi masyarakat dalam meningkatkan pengetahuan dan informasi mengenai HTR, termasuk mengakses informasi serta mebangun kerjasama dengan pihak-pihak terkait. Saat ini kondisi di lapangan keberadaan penyuluh sebagai tenaga pendamping masih sangat minim. Peningkatan kualitas penyuluhan dapat dilakukan dengan peningkatan kualitas materi penyuluhan dan teknis pelaksanaan penyuluhan dengan metode penyuluhan yang sesuai dengan kondisi dan harapan masyarakat. Sedangkan peningkatan kuantitas penyuluhan dilakukan dengan lebih meningkatkan intensitas atau frekuensi penyuluhan sebagai proses belajar bersama untuk lebih meningkatkan partisipasi masyarakat. Untuk itu peran dari Dinas Kehutanan dan KPH Gedong Wani dalam program pembangunan hutan rakyat khususnya dalam hal kualitas dan kuantitas penyuluhan agar lebih ditingkatkan.

Strategi ST bertujuan untuk mengembalikan fungsi hutan dan mencegah agar pemukiman liar tidak semakin bertambah. Selain itu juga mencegah adanya pemindah kuasaan atas lahan. Oleh karena itu, strategi yang dapat dilakukan adalah dengan memanfaatkan potensi lahan yang tersedia dengan menerapkan pola SFM (Suistanable
Forest Management). Pengelolaan hutan lestari ( SFM) adalah pengelolaan hutan sesuai dengan prinsip-prinsip pembangunan berkelanjutan. Pengelolaan hutan lestari menggunakan tujuan sosial, ekonomi dan lingkungan yang sangat luas.

Strategi WT bertujuan untuk memberikan kepastian pada masyarakat mengenai pasar dikarenakan kekhawatiran masyarakat selama ini adalah mengenai pasar. Masyarakat mengeluhkan belum adanya multipihak yang bekerja sama dengan masyarakat terkait dengan memasarkan hasil panen. Mutaqin (2008) mengemukakan bahwa penyediaan pasar yang dapat diakses oleh masyarakat sekitar hutan merupakan fokus utama dalam implementasi kebijakan pemberdayaan ekonomi masyarakat sekitar hutan. Oleh karena itu, issu mengenai kelangkaan kayu dan pemasaran dapat dijadikan rangsangan bagi masyarakat untuk menanam tanaman berkayu.

Selanjutnya adalah tahap keputusan yang merupakan tahap untuk menentukan strategi terbaik yang dapat dijalankan oleh KPH XIV Gedong Wani selaku fasilitator program HTR dari alternatif-alternatif yang diperoleh dari hasil analisis SWOT. Dari beberapa strategi yaitu dimana yang harus dilakukan oleh $\mathrm{KPH}$ XIV Gedong Wani adalah meningkatkan kualitas dan kuantitas penyuluh. Peningkatan kualitas penyuluhan dapat dilakukan dengan peningkatan kualitas materi penyuluhan dan teknis pelaksanaan penyuluhan dengan metode penyuluhan yang sesuai dengan kondisi dan harapan masyarakat. Sedangkan peningkatan kuantitas penyuluhan dilakukan dengan lebih meningkatkan intensitas atau frekuensi penyuluhan sebagai proses belajar bersama untuk lebih meningkatkan partisipasi masyarakat. Untuk itu peran dari Dinas Kehutanan dan KPH Gedong Wani dalam program pembangunan hutan rakyat khususnya dalam hal kualitas dan kuantitas penyuluhan agar lebih ditingkatkan.

\section{SIMPULAN}

Partisipasi masyarakat terhadap pembangunan HTR secara keseluruhan tergolong sedang dikarenakan beberapa faktor, dimana partisipasi masyarakat yang sedang dapat menghambat atau bahkan dapat mendukung kesuksesan dari implementasi pembangunan HTR. Untuk itu diperlukan strategi implementasi kebijakan hutan tanaman rakyat, yaitu dengan meningkatkan kualitas dan kuantitas penyuluh.

\section{UCAPAN TERIMAKASIH}

Penelitian ini dapat dilaksanakan atas sponsor tunggal yaitu DIPA BLU Unila Tahun 2017 melalui Skema Hibah Penelitian Pascasarjana Universitas Lampung tahun 2017. Karena itu kepada sposnsor patut kami ucapkan terima kasih. 


\section{DAFTAR PUSTAKA}

Desmiwati, N.F.N. (2016). “Studi Tentang Persepsi Dan Tingkat Partisipasi Petani Penggarap Di Hutan Penelitian Parungpanjang." Jurnal Perbenihan Tanaman Hutan 4.2 (2016): 109-124.

Dishut Provinsi Lampung. (2013). Tata Hutan dan Rencana Pengelolan Hutan Jangka Panjang 2014-2023 UPTD KPHP Gedong Wani, Bandar Lampung: Dinas Kehutanan Provinsi Lampung.

Emila, S. (2007). Hutan Tanaman Rakyat (HTR): Agenda Baru untuk

Pengentasan Kemiskinan? Warta Tenure Nomor 4 Februari 2007

Hakim, I. (2009). Kajian Kelembagaan dan Kebijakan hutan Tanaman Rakyat. Jurnal Analisis Kebijakan Kehutanan 6 (1) : 27-41

Kumba, F.F. (2003). Farmer participation in agricultural research and extension service in Namibia. Journal IntAgric Extension Edu. 10 (3): 47-55.

Nawir, A.A., Kassa, H., Sandewall, M., Dore, D., Campbell, B., Ohlsson, B, and Bekele, M. (2007). Stimulating Smallholder Tree Planting - Lessons from Africa andAsia. Unasylva 228 Vol. 58, 2007

Rangkuti, F. (2008). Analisis SWOT Teknik Membedah Kasus Bisnis (Reorientasi Konsep Perencanaan Strategis untuk Menghadapi Abad 21). Jakarta: PT. Gramedia Pustaka Utama.
Rosalia, F. \& Ratnasari, Y. (2016). Analisis Pengelolaan Hutan Kemasyarakatan Di Sekitar Kawasan Hutan Lindung Register 30 Kabupaten Tanggamus Provinsi Lampung Tahun 2010. Sosiohumaniora, 18(1)

Senoaji, G. (2011). Kondisi Sosial Ekonomi Masyarakat Sekitar Hutan Lindung Bukit Daun di Bengkulu. Sosiohumaniora, 13 (1), 1.

Simon, H. (2000). Hutan Jati dan Kemakmuran. Problematika dan Strategi Pemecahan. Yogyakarta: BIGRAF Publishing.

Simon, H. (2001). Pengelolaan Hutan Bersama Rakyat (Cooperative Forest Management) Teori dan Aplikasi pada hutan Jati di Jawa. Yogyakarta: Biograf Publishing.

Sumanto, S.E. (2009). "Kebijakan pengembangan perhutanan sosial dalam perspektif resolusi konflik." Jurnal Analisis Kebijakan Kehutanan 6 (1)

Stringer, L.C. and Paavola, J. (2013). Participation in environmental conservation and protected area management in Romania: a review of three case studies. Environmental Conservation, 40(2), 138-146

Winarto H. (2003). Partisipasi Masyarakat dalam Kegiatan Agroforestry [tesis[. Bogor: Program Pascasarjana, Institut Pertanian Bogor 